\title{
PENERAPAN MODEL PEMBELAJARAN KOOPERATIF JIGSAW UNTUK MENINGKATKAN MOTIVASI SISWA PADA PELAJARAN PKn KELAS IV SDN 101775 SAMPALI
}

\author{
Ida Eriani \\ Surel: gusni_sordiani@yahoo.com
}

\begin{abstract}
ABSTRAK
Tujuan penelitian untuk meningkatkan motivasi belajar siswa melalui model pembelajaran kooperatif tipe JIGSAW pada pelajaran PKn kelas IV SDN 101774 Sampali. Teknik pengumpulan data yang digunakan adalah observasi terhadap pelaksanaan pembelajaran yang dilakukan oleh siswa dan penyajian pembelajaran yang dilakukan oleh guru. Pada siklus I pertemuan I dan pertemuan II presentase siswa yang termotivasi secara klasikal yaitu 9,37\% dan 31,25\%, sedangkan tingkat keberhasilan mengajar guru yaitu $61,11 \%$ dan $72,22 \%$, pada siklus I tergolong tidak berhasil. Pada siklus II hasil yang diperoleh mengalami peningkatan yaitu pada siklus II pertemuan I persentase siswa yang termotivasi secara klasikal yaitu 65,62\% dan tingkat keberhasilan mengajar guru yaitu $84,72 \%$ dan tergolong berhasil. Pada siklus II pertemuan II persentase siswa yang termotivasi secara klasikal yaitu 100\% dan tingkat keberhasilan mengajar guru yaitu $87,50 \%$. Hasil penelitian yang dilakukan dari siklus I-II menunjukkan peningkatan pada motvasi belajar siswa dan tingkat keberhasilan mengajar guru.
\end{abstract}

Kata Kunci: Jigsaw, Motivasi Belajar, Pelajaran PKn

\section{PENDAHULUAN}

Pendidikan merupakan salah satu proses pembentukan sikap, kepribadian dan keterampilan manusia dalam mengahadapi cita-cita dimasa depan. Dalam proses pembentukan sikap, kepribadian dan keterampilan akan memberikan hasil yang bervariasi sesuai dengan kemampuan dan perkembangan manusia itu sendiri. Sesuai dengan Kurikulum Tingkat Satuan Pendidikan (KTSP), fungsi mata pelajaran PKn adalah wahana untuk membentuk warga negara yang cerdas, terampil dan berkarakter, setia kepada bangsa dan negara Indonesia dengan merefleksikan dirinya dalam kebiasaan berfikir dan bertindak sesuai dengan amanat Pancasila dan UUD 1945.

Mata pelajaran Pendidikan Kewarganegaraan diharapkan dapat mewujudkan proses pendidikan yang integral dan mampu mengembangkan kepribadian warga negara yang partisipatif bertanggung jawab yang akan menjadi landasan untuk perkembangan masyarakat Indonesia yang demokratis.

Dari hasil pengamatan di SD Negeri No.101775 Sampali di Kecamatan Percut Sei Tuan dengan melakukan wawancara kepada guru

Guru SDN 101775 Sampali 
kelas IV dengan jumlah siswa yaitu 32 orang yang terdiri dari 15 orang siswa laki-laki dan 17 siswa perempuan, dimana nilai ulangan harian yang didapat yaitu rentang antara 4,0-6,5 yaitu sebanyak $75 \%$ siswa dikelas masih mendapat nilai dibawah $<70$, sedangkan $25 \%$ mendapat nilai rentang antara 6,5-8,0. Sedangkan nilai ketuntasan yang ingin dicapai 70 sehingga nilai ratarata siswa tidak mencapai nilai ketuntasan yang diharapkan.

Banyak faktor yang menyebabkan hasil belajar PKn siswa rendah yaitu faktor internal dan eksternal siswa. Faktor internal antara lain: motvasi belajar, intelegensi, kebiasaan dan rasa percaya diri. Sedangkan faktor eksternal adalah faktor yang terdapat dari luar siswa, seperti guru sebagai pengajar, strategi pembelajaran, sarana dan prasarana, dan lingkungan.

Dalam pembelajaran $\mathrm{PKn}$, guru sering menggunakan metode pembelajaran ceramah yang bersifat konvensional yang mengakibatkan pembelajaran berpusat pada guru. Guru menjelaskan hanya sebatas materi yang harus diselesaikan dalam beberapa pertemuan karena mengejar target sesuai dengan kurikulum dan memberikan soal-soal latihan sehingga dapat membuat siswa jenuh. Metode pembelajaran ini tidak dapat membangkitkan semangat siswa dalam belajar. Hal ini tampak perilaku siswa yang cenderung hanya mendengar dan mencatat pelajaran yang diberikan guru.

Pembelajaran

yang

disampaikan dalam pembelajaran PKn kurang menarik bagi siswa, hal ini dapat dilihat masih adanya siswa yang berbicara dengan teman sebangku pada saat guru menjelaskan materi pelajaran.

Dalam proses pembelajaran PKn banyak siswa yang tidak mau bertanya apalagi mengemukakan pendapat atau saran tentang materi yang diberikan, hanya sebagian saja yang aktif dan sebagian kurang mampu mengemukakan pendapat.

Dari masalah yang dikemukakan di atas, perlu dicari strategi dan model pembelajaran baru yang dapat melibatkan siswa secara aktif. Pembelajaran yang mengutamakan kompetensi yang berpusat pada siswa, memberikan pembelajaran dan pengalaman belajar yang relevan dalam kehidupan nyata. Di sinilah guru dituntut untuk merancang kegiatan pembelajaran yang mampu mengembangkan kompetensi, baik ranah kognitif, afektif maupun psikomotorik siswa. Model pembelajaran yang berpusat pada siswa dan penciptaan suasana yang menyenangkan sangat diperlukan untuk meningkatkan hasil belajar siswa dalam mata pelajaran PKn.

Berdasarkan uraian pada batasan masalah diatas maka yang menjadi rumusan masalah penelitian ini adalah : "Apakah dengan 
menggunakan Model Pembelajaran Kooperatif tipe Jigsaw dapat meningkatkan hasil belajar siswa pada Mata Pelajaran PKn materi pokok dampak Globalisasi di kelas IV SD Negeri 101775 Sampali T.A 2015/2016?".

\section{METODE PENELITIAN}

Jenis penelitian ini adalah penelitian tindakan kelas (PTK). PTK dilaksanakan dalam bentuk proses pengkajian berdasarkan 4 tahap pada setiap siklus, yaitu (1) perencanaan, (2) tindakan, (3) pengamatan, dan (4) refleksi.

Tempat penelitian ini dilaksanakan di kelas IV SDN 101774 Sampali. Teknik pengumpulan data dalam penelitian ini diperoleh melalui observasi, yaitu dengan mengamati terhadap pelaksanaan pembelajaran yang dilakukan oleh siswa dan penyajian pembelajaran yang dilakukan oleh guru.

\section{HASIL DAN PEMBAHASAN \\ Siklus I}

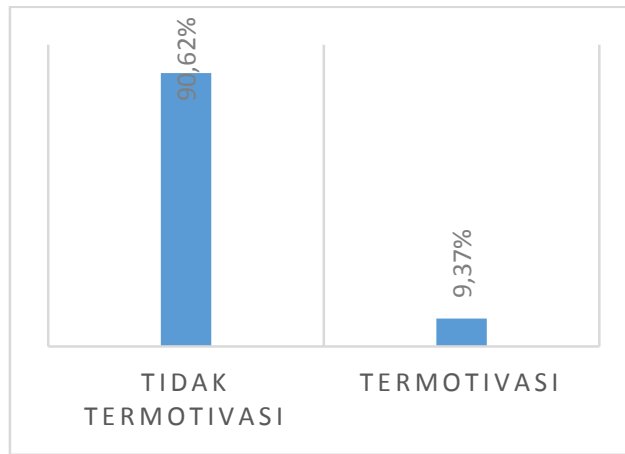

\section{Presentase Motivasi Siswa Siklus I pertemuan I}

Berdasarkan hasil observasi motivasi belajar siswa pada siklus I pertemuan I dapat juga diketahui secara keseluruhan presentase indikator-indikator yang ditunjukkan oleh siswa pada saat proses pembelajaran, yaitu : 1) tekun menghadapi tugas $(35,94 \%), 2)$ ulet menghadapi kesulitan $(22,66 \%), 3)$ menunjukkan minat terhadap bermacam-macam masalah $(51,56 \%)$, 4) lebih senang bekerja mandiri $(17,16 \%), 5)$ cepat bosan pada tugastugas yang rutin atau berulang-ulang $(24,22 \%), 6)$ dapat mempertahankan pendapatnya $(20,31 \%)$, dan 7) senang mencari dan memecahkan soal-soal $(41,40 \%)$. Dan dari data tersebut dapat disimpulkan bahwa indikator yang lebih banyak ditunjukkan oleh seluruh siswa yaitu menunjukkan minat terhadap bermacam-macam masalah $(51,56 \%)$.

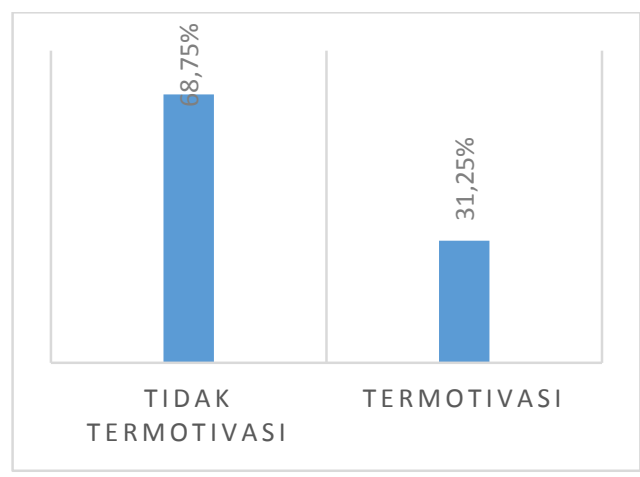

\section{Presentase Motivasi Siswa Siklus I pertemuan II}

Berdasarkan hasil observasi motivasi belajar siswa pada siklus I pertemuan II dapat juga diketahui secara keseluruhan presentase indikator-indikator yang ditunjukkan oleh siswa pada saat proses pembelajaran, yaitu : 1) tekun menghadapi tugas $(57,81 \%), 2)$ ulet 
menghadapi kesulitan (46,09\%), 3) menunjukkan minat terhadap bermacam-macam masalah $(49,22 \%)$, 4) lebih senang bekerja mandiri $(38,28 \%), 5)$ cepat bosan pada tugastugas yang rutin atau berulang-ulang $(28,91 \%), 6)$ dapat mempertahankan pendapatnya $(28,12 \%)$, dan 7$)$ senang mencari dan memecahkan soal-soal $(57,81 \%)$. Dari data tersebut dapat disimpulkan bahwa indikator yang ditunjukkan oleh siswa mengalami peningkatan dari hasil observasi pertemuan I dan indikator yang lebih banyak ditunjukkan oleh seluruh siswa yaitu tekun menghadapi tugas $(57,81 \%)$ dan senang mencari dan memecahkan soal-soal $(57,81 \%)$.

\section{Siklus II}

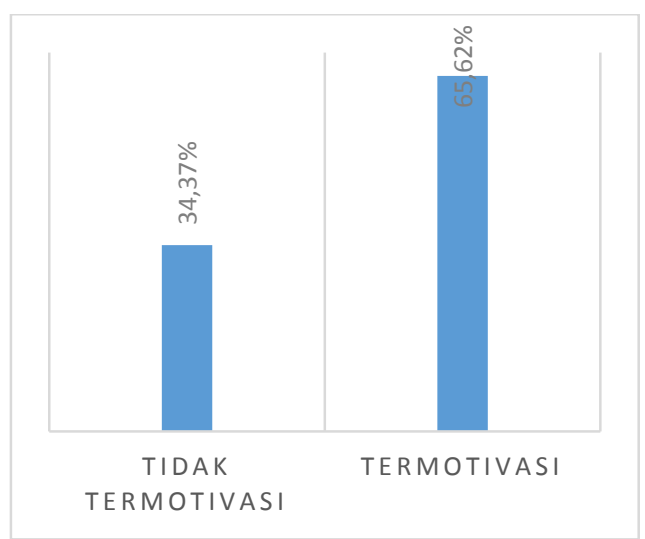

\section{Presentase Motivasi Siswa Siklus II Pertemuan I}

Berdasarkan hasil observasi motivasi belajar siswa pada siklus II pertemuan I dapat juga diketahui secara keseluruhan presentase indikator-indikator yang ditunjukkan oleh siswa pada saat proses pembelajaran, yaitu : 1) tekun menghadapi tugas $(89,84 \%), 2)$ ulet menghadapi kesulitan $(82,81 \%), 3)$ menunjukkan minat terhadap bermacam-macam masalah $(73,44 \%)$, 4) lebih senang bekerja mandiri $(57,03 \%), 5)$ cepat bosan pada tugastugas yang rutin atau berulang-ulang $(59,37 \%), 6)$ dapat mempertahankan pendapatnya $(38,28 \%)$, dan 7$)$ senang mencari dan memecahkan soal-soal $(82,81 \%)$. Dari data tersebut dapat disimpulkan bahwa indikator yang ditunjukkan oleh siswa mengalami peningkatan dari hasil observasi siklus I dan indikator yang lebih banyak ditunjukkan oleh seluruh siswa yaitu tekun menghadapi tugas $(89,84 \%)$.

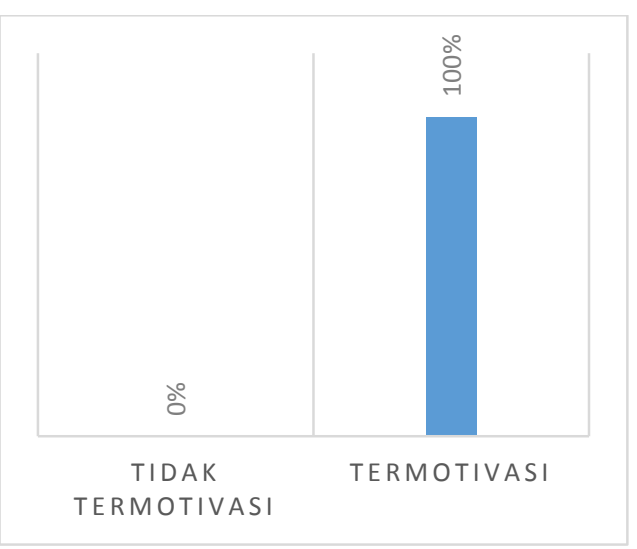

\section{Presentase Motivasi Siswa Siklus II Pertemuan II}

Berdasarkan hasil observasi motivasi belajar siswa pada siklus II pertemuan II dapat juga diketahui secara keseluruhan presentase indikator-indikator yang ditunjukkan oleh siswa pada saat proses pembelajaran, yaitu : 1) tekun menghadapi tugas $(91,41 \%), 2)$ ulet menghadapi kesulitan $(82,03 \%), 3)$ 
menunjukkan minat terhadap bermacam-macam masalah $(73,44 \%)$, 4) lebih senang bekerja mandiri $(75 \%)$, 5) cepat bosan pada tugastugas yang rutin atau berulang-ulang $(73,44 \%), 6)$ dapat mempertahankan pendapatnya $(74,22 \%)$, dan 7$)$ senang mencari dan memecahkan soal-soal $(87,5 \%)$. Dari data tersebut dapat disimpulkan bahwa seluruh indikator stelah mengalami peningkatan lebih baik.

\section{Pembahasan}

Setelah melakukan 2 siklus penelitian dengan menggunakan model pembelajaran kooperatif tipe JIGSAWpada pelajaran $\mathrm{PKn}$ telah terbukti adanya peningkatan yang terjadi terhadap motivasi belajar siswa kelas V yang dapat dilihat baik secara individual maupun klasikal. Motivasi siswa pada siklus I pertemuan I terdapat 3 orang dari 32 orang siswa yang termotivasi dalam belajar. Presentase siswa yang termotivasi secara klasikal yaitu 9,37\%. Ketiga siswa tersebut dikategorikan memiliki motivasi sedang. Dan secara individual dapat dilihat dari nilai dari yang diperoleh setiap siswa masih banyak yang dikategorikan rendah motivasi belajarnya.

Pada siklus I pertemuan II terdapat 10 orang dari 32 orang siswa yang termotivasi. Persentase siswa yang termotivasi secara klasikal yaitu $31,25 \%$. Terdapat 8 (25\%) orang siswa yang dikategorikan memiliki motivasi belajar sedang dan 2
$(6,25 \%)$ orang siswa yang dikategorikan memiliki motivasi belajar tinggi. Dan secara individual sudah mulai meningkat siswa yang termotivasi meskipun masih banyak yang dikategorikan rendah motivasinya. Berdasarkan kesimpulan sementara bahwa motivasi siswa dalam mengikuti pelajaran PKn belum meningkat sehingga perlu perbaikan dan dilakukan siklus II.

Setelah dilakukan perbaikan pembelajaran dengan menggunakan model pembelajaran kooperatif tipe Jigsaw siswa lebih termotivasi dalam belajar. Pada siklus II pertemuan I ada 21 0rang dari 32 orang siswa yang termotivasi dalam belajar. Persentase siswa yang termotivasi secara klasikal yaitu $65,62 \%$. Terdapat 16 orang siswa $(50 \%)$ yang dikategorikan memiliki motivasi belajar sedang dan 5 orang siswa $(15,62 \%)$ yang dikategorikan memiliki motivasi belajar tinggi. Dan secara individual sudah lebih sedikit siswa yang dikategorikan rendah motivasi belajarnya.

Pada siklus II pertemuan II terdapat 32 orang dari 32 orang siswa. Persentase siswa yang termotivasi secara klasikal yaitu $100 \%$. Terdapat 17 orang siswa $(53,12 \%)$ yang dikategorikan memiliki motivasi belajar sedang dan 15 orang siswa $(46,87 \%)$ yang dikategorikan memiliki motivasi belajar tinggi. Sedangkan siswa yang tidak termotivasi tidak ada. 


\section{SIMPULAN}

Berdasarkan hasil penelitian yang telah dilakukan pada siklus I dan II, maka diperoleh kesimpulan bahwa dengan menerapkan model pembelajaran kooperatif tipe JIGSAW dapat meningkatkan motivasi belajar siswa pada pelajaran Matematika kelas V SD Negeri 101774 Sampali tahun ajaran 2013/2014. Presentase siswa yang termotivasi pada siklus I pertemuan $\quad 9,37 \% \quad$ kemudian meningkat pada siklus I pertemuan II yaitu $31,25 \%$, pada siklus II pertemuan I meningkat menjadi $65,62 \%$ dan pada siklus II pertemuan II meningkat menjadi $100 \%$.

Meningkatnya motivasi belajar siswa didukung juga pada tingkat keberhasilan mengajar peneliti. Pada siklus I pertemuan I tingkat keberhasilan mengajar peneliti yaitu $61,11 \%$ yang dikategorikan tidak berhasil dan pada siklus I pertemuan II dengan persentase $72,22 \%$ masih dikategorikan tidak berhasil. Pada siklus II pertemuan II persentase keberhasilan mengajar peneliti yaitu $84,72 \%$ yang dikategorikan berhasil dan meningkat pada siklus II pertemuan II yaitu $87,5 \%$.

Upaya yang dilakukan peneliti untuk meningkatkan motivasi belajar siswa pada pelajaran Matematika yaitu dengan menerapkan model pembelajaran kooperatif tipe JIGSAW yaitu dengan membimbing siswa dengan membentuk kelompok asal dan kelompok ahli yang membantu siswa untuk memahami materi dan mengarahkan siswa untuk terlibat aktif dalam pelajaran di kelas.

\section{DAFTAR RUJUKAN}

Astuti, Lusia Tri, dkk. 2009. PKn Untuk Sekolah Dasar Kelas $I V$. Jakarta: Pusat Perbukuan. Departemen Pendidikan Nasional.

Daryanto dan Muljo Rahardjo. 2012. Model Pembelajaran Inovatif. Malang: Gava Media.

Dewi, Rosmala. 2010. Profesionalisasi Guru Melalui PTK. Medan: Pasca Sarjana Unimed.

Dimyati dan Mudjiono. 2009. Belajar dan Pembelajaran. Jakarta: Rineka Cipta.

Djaali, H. 2008. Psikologi Pendidikan. Jakarta : Bumi Aksara.

Djamarah, Syaiful Bahri. 2011. Psikologi Belajar. Jakarta: Rineka Cipta.

Huda, Miftahul. 2011. Cooperative Learning (Metode, Teknik, Struktur dan Model Terapan). Yogyakarta: Pusaka Pelajar.

Hudojo, Herman. 2005. Pengembangan Kurikulum dan Pembelajaran PKN. Malang: Penerbit Universitas Negeri Malang.

Istarani. 2010. Penelitian Tindakan Kelas (PTK). Medan: Iscom Medan. 
Isjoni. 2009. Pembelajaran

Kooperatif. Yogyakarta:

Pustaka Belajar.

Purwanto. 2011. Evaluasi Hasil Belajar. Yogyakarta: Pustaka Belajar.

Rusman. 2012. Model-Model Pembelajaran mengembangkan Profesionalime Guru. Jakarta: Rajawali Pers.

Sardiman. 2010. Interaksi dan Motivasi Belajar Mengajar. Jakarta : Rajawali Pers.

Solihatin, Etin. 2012. Strategi Pembelajaran PPKN. Jakarta: Bumi Aksara.

Sumiati, Ati dan Bestari Prayoga. 2008. Pendidikan Kewarganegaraan 4. Jakarta: DEPDIKNAS.

Trimo. 2008. Meningkatkan Hasil Belajar PKn melalui Metode Snowball Throwing. http://researchengines.com/0408trimo. html. Diakses 28 februari 2012.

Yamin, Martinis. 2011. Paradigma Baru Pembelajaran. Jakarta: Gaung Persada. 